\title{
The mice's hematological effect of given the Staphylococcus aureus and Persea americana
}

\author{
Christin M. Santosa ${ }^{1 *}$, Dorothea V. Megarani ${ }^{1}$, Dinar Arifianto ${ }^{1}$, and Siti I.O. Salasia ${ }^{1}$ \\ ${ }^{1}$ Department of Clinical Pathology, Faculty of Veterinary Medicine, Universitas Gadjah Mada \\ Yogyakarta, Yogyakarta Special Region, Indonesia
}

\begin{abstract}
Staphylococcus aureus is often the cause of various diseases and food poisoning in animals and humans. Avocado seeds (Persea americana, Mill) contain important compounds that have antimicrobial activity. This study aimed to observe the hematological dynamics of mice (Mus musculus domesticus) infected with $S$. aureus and induced by $P$. americana extract. $\mathrm{BALB} / \mathrm{c}$ male mice aged 12 weeks were divided into 6 groups of 5 in each group, named K-1, K-2, K-3, K-4, K-5, and K-6. All groups were infected with $S$. aureus $1 \times 10^{8} \mathrm{CFU}$ cell $/ \mathrm{mL}$ intraperitoneally (IP) on day 0 . After the blood sample was taken, then K-1 was given a single dose of tetracyclin $130 \mathrm{mg} / \mathrm{kg}$ BW, K-2 was given $130 \mathrm{mg} / \mathrm{kb}$ BW of erythromycin, K-3 was given aquabidest (placebo), K-4 was given $P$. americana extract $300 \mathrm{mg} / \mathrm{kg} \mathrm{BW}, \mathrm{K}-5$ at a dose $600 \mathrm{mg} / \mathrm{kg} \mathrm{BW}$ and K-6 at a dose $1200 \mathrm{mg} / \mathrm{kg} \mathrm{BW}$. The treatment was given for 7 consecutive days, then a second blood sample was taken and analyzed with the VetScan-HM5 analyzer and interpreted. It was concluded that $S$. aureus infection caused leukopenia and was potentially followed by lymphopenia, neutrophilia, and monocytosis. The occurrence of microcytosis can lead to anemia, which can be categorized as microcytic hypochromic or normocytic normochromic. Administration of $P$. americana extract at a dose $300 \mathrm{mg} / \mathrm{kg} \mathrm{BW}$ (K-4) for 7 days after $S$. aureus infection was found to be effective in improving hematological values in mice back to normal.
\end{abstract}

Keywords: Staphylococcus aureus, Persea americana, Mus musculus domesticus, erythrocytes, leukocytes

\section{Introduction}

Staphylococcus aureus can cause various diseases and food poisoning in both animals and humans, as the main reservoir, even though these bacteria are easily found in the environment. ${ }^{[1]}$ Staphylococcus aureus infection, especially methicillin resistant S. aureus (MRSA) is difficult to treat because it is known to be resistant to various antibiotics. ${ }^{[2]}$

The proximity between humans and animals allows this transmission. Methicillin-resistant Staphylococcus aureus infection, which spreads in various hospitals in Bulgaria, can be prolonged due to horizontal transmission. ${ }^{[3]}$ The existence of MRSA transmission between pigs and breeders and their family members has also been investigated. ${ }^{[4]}$ Methicillin-resistant Staphylococcus aureus colonization in pigs in the Netherlands has implications as a source of

\footnotetext{
*Corresponding author: jchrist@ugm.ac.id
} 
infection, it was found that MRSA isolates had been obtained from 3 human patients in 20042005 period. ${ }^{[5]}$ Phenotype and genotype studies of $S$. aureus from skin infections in humans, comparative studies of cattle in Indonesia and Germany, MRSA studies in cows with subclinical mastitis and the genetic association of MRSA in cattle and humans demonstrate this closeness. ${ }^{[6-}$ 11]

Avocado plant (Persea Americana, Mill) is one of the abundant plants in Indonesia. The seeds are not used and considered waste, but they have many benefits. According to the research, it shows that the ethanol extract of avocado seeds has antibacterial activity (MIC $=104.2-416.7$ $\mu \mathrm{g} / \mathrm{mL}$ ) against gram-negative and positive bacteria. ${ }^{[12]}$ The water extract is able to inhibit the growth of Staphylococcus epidermidis (MIC $=354.2 \mu \mathrm{g} / \mathrm{mL}$ ), while non-polar extracts hexane and chloroform have antibacterial activity against Escherichia coli, antihypercholesterolemia, and inhibits growth of Streptococcus mutans in vitro. ${ }^{[13-15]}$ Secondary metabolite components such as saponins, alkaloids, tannins, triterpenoids, and flavonoids, phytosterols, furanoic acid, oleic acid and linoleic acid, oxalic and phytic with varying proportions in avocado seeds, and other phytochemical substances play a role in these activities. ${ }^{[16-18]}$ The purpose of this study was to observe the blood dynamics of mice (Mus musculus domesticus) which were infected with Staphylococcus aureus and then induced extracts of Persea americana, Mill.

\section{Materials And Methods}

\subsection{Clearance}

All procedures performed in this research were approved by the Animal Care and Use Committee, Faculty of Veterinary Medicine, Universitas Gadjah Mada No. 0023/ECFICI/Int./2018.

\subsection{Persea americana seeds extraction}

The process of phytochemical compound withdrawal in $P$. americana seeds used maceration method with 96\% methanol and the compound yield was $12.8 \%$. The extract was then concentrated in the form of a paste and the sensitivity of $S$. aureus was tested using the KirbyBauer Disc Diffusion Method in order to obtain the optimal concentration of testing in experimental mice. ${ }^{[19]}$ Erythromycin and tetracycline were used as antibiotic controls.

\subsection{Inoculum preparations}

Strain isolate of methicillin-resistant $S$. aureus was kindly supplied by Prof. Siti I.O. Salasia's collections. Four to 6 colonies aged 16-24 hours were selected from the blood agar medium containing $S$. aureus, then standardized to the $0.5 \mathrm{McFarland}$ standard, which had a turbidity comparable to $1 \times 10^{8} \mathrm{CFU} / \mathrm{mL}$.

\subsection{Animals and husbandry}

Six random groups of male BALB/c strain mice aged 12 weeks, body weight ranging from 45 to 50 grams, each group containing 5 mice. Adaptation to the new environment was carried out for 2 weeks at the research site consisting of a cage, feed, sleeping mats as well as a place to eat and drink. The overall research was carried out at the Experimental Animal Laboratory, Faculty of Veterinary Medicine, Universitas Gadjah Mada for 30 days by feeding mice using AD2 feed and drinking water ad libitum. 
The $100 \%$ dilution concentration of avocado seed extract which gave the best results on the inhibition of $S$. aureus, namely at $13 \%$ was used for this test. ${ }^{[20]}$ BALB/c male mice aged 12 weeks were divided into 6 groups of 5 in each group, named K-1, K-2, K-3, K-4, K-5, and K-6. All groups were infected with $S$. aureus $1 \times 10^{\wedge} 8 \mathrm{CFU} / \mathrm{mL}$ intraperitoneal (IP) on day 0 . After the blood sample was taken, then K-1 was given a single dose tetracyclin $130 \mathrm{mg} / \mathrm{kg} \mathrm{BW}, \mathrm{K}-2$ was given $130 \mathrm{mg} / \mathrm{kb} \mathrm{BW}$ of erythromycin, $\mathrm{K}-3$ was given aquabidest (placebo), $\mathrm{K}-4$ was given $P$. americana extract $300 \mathrm{mg} / \mathrm{kg} \mathrm{BW}, \mathrm{K}-5$ at a dose $600 \mathrm{mg} / \mathrm{kg} \mathrm{BW}$ and K-6 at a dose $1200 \mathrm{mg} / \mathrm{kg}$ $\mathrm{BW}$. The treatment was given for 7 consecutive days.

\subsection{Blood collection and measurements}

Blood was collected on day 1 and at the end of the study (day 7) through the orbital sinus under the influence of ketamine anesthesia. Blood samples were analyzed using the automatic hemacounter Abaxis VetScan HM5 with impedance technique. Types of examination included total erythrocytes count, hematocrit value, hemoglobin level, total number of leukocytes and differential leukocytes. The results data were compared with the data on normal/healthy mice, then the interpretation was concluded.

\section{Results And Discussions}

The results of hematological examination of mice on day 1(after being infected with S. aureus and before the treatment of Persea americana extract) were listed in Figure 1. The results of the calculation of the total number of leukocytes (WBC) and differential leukocytes (consisting of lymphocytes, monocytes, neutrophils, eosinophils, basophils) $\mathrm{K}-1$ on the first examination showed leukopenia accompanied by lymphopenia. The results of the calculation of the total number of leukocytes on K-3 and K-2 are in the normal range, but are almost close to the lower limit, which allows leukopenia or a reduction in the total number of leukocytes. ${ }^{[21-25]}$ The results of leukocyte differential calculations on K-3 showed the absolute number of each type of leukocytes was normal, while on K-2 showed a decrease in the absolute number of lymphocytes (lymphopenia), an increase in the absolute number of monocytes (monocytosis), and an increase in the absolute number of neutrophils (neutrophilia). This change was also seen in all groups, because mice has been infected by $S$. aureus. The results of the calculation of the total number of K-4 and K-5 leukocytes showed that leukopenia was accompanied by lymphopenia and neutrophilia. The results of the calculation of the total number of K-6 leukocytes showed that leukopenia was accompanied by lymphopenia, neutrophilia, and monocytosis.

Lymphocytes have a dominant percentage, $70-80 \%$ of the total number of leukocytes so that the main cause of the decrease in the total number of leukocytes is generally due to a decrease in the number of lymphocytes, unless neutrophils drop in an extreme way, it will only have an impact on total leukocytes. ${ }^{22,23}$ These results indicate that $S$. aureus infection causes a decrease in the total number of leukocytes which could potentially be followed by a decrease in the absolute number of lymphocytes and an increase in neutrophils and monocytes. 


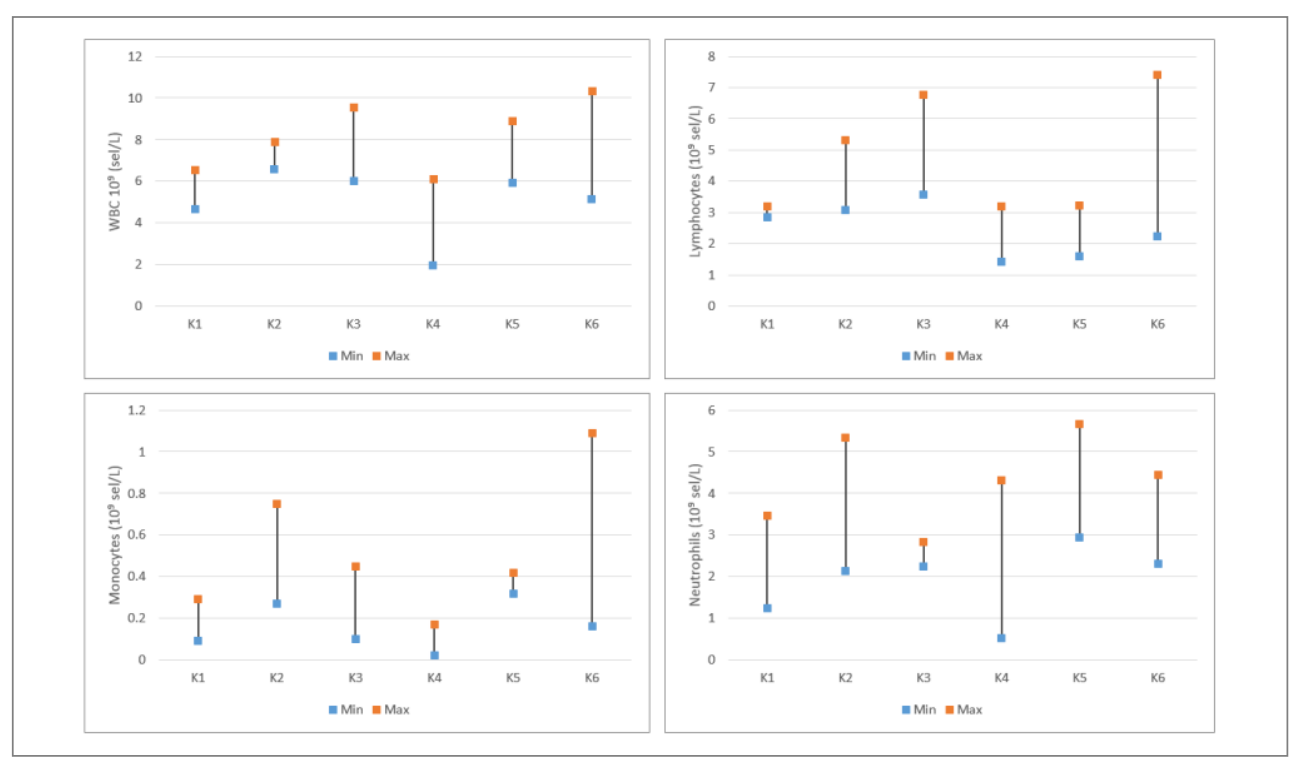

Fig. 1. The results of the first measurement for leukocytes and leukocyte differentials in 6 groups of mice after being infected with $S$. aureus (K-1, K-2, K-3, K-4, K-5, K-6) $1 \times 10^{\wedge} 8$ CFU bakteri/mL intraperitoneal (IP)

The results of the total number of erythrocyte calculation (RBC), hemoglobin levels (HGB), and hematocrit values (HCT) are summarized in Figure 2 below. These three components are the basic parameters for determining the anemia status of an individual. Based on the calculation of the formula, the values of Mean Corpuscular Volume (MCV) and Mean Corpuscular Hemoglobin Concentration (MCHC) are obtained which serve as guidelines in determining the type classification of anemia based on cell morphology. ${ }^{[23]}$

The results of the calculation of RBC, HGB, and HCT showed a normal range at K-1, K-2, and K-3 but there was an increase in the number of small cells (microcytosis). Microcytosis in all groups of mice indicated the need for more erythrocytes, generally in a state preceding anemia or anemia itself, thereby stimulating increased production in bone marrow or extramedullary hematopoiesis. This condition can be seen also in the increase in the value of hematocrit or packed cell volume.

The results of the K-4 examination showed anemia because the results of the erythrocyte count and the examination of $\mathrm{Hb}$ levels fell from normal, and the classification was microcytic hypochromic because the values of MCV and MCHC fell from normal. This type of anemia generally occurs in all circumstances which in principle lead to deficiency of iron or vitamin B6. ${ }^{[21]}$ The result of K-5 examination showed normocytic normochromic anemia because the $\mathrm{MCV}$ and MCHC values were normal. This classification of anemia needs to be watched out if the norm is assumed to be no erythrocyte regeneration or no reticulocyte found, which means that defects have occurred which causes the cessation of erythrocyte production. In this case, normocytic normochromic anemia showed adequate hemoglobin levels and erythrocyte size. The results of the K-6 examination showed microcytosis, the same as the results of the K-1, K2, and K-3 examinations.

It can be concluded that $S$. aureus infection has the potential to cause anemia, which can further be categorized into microcytic hypochromic or normocytic normochromic types. One mouse, each K-4, K-5 and K-6 died after being infected with $S$. aureus. The results of the blood image of dead mice showed microcytic normochromic anemia at K-4 and K-6 with very low threshold results from normal, while K-5 besides anemia was also accompanied by leukopenia and lymphopenia. 


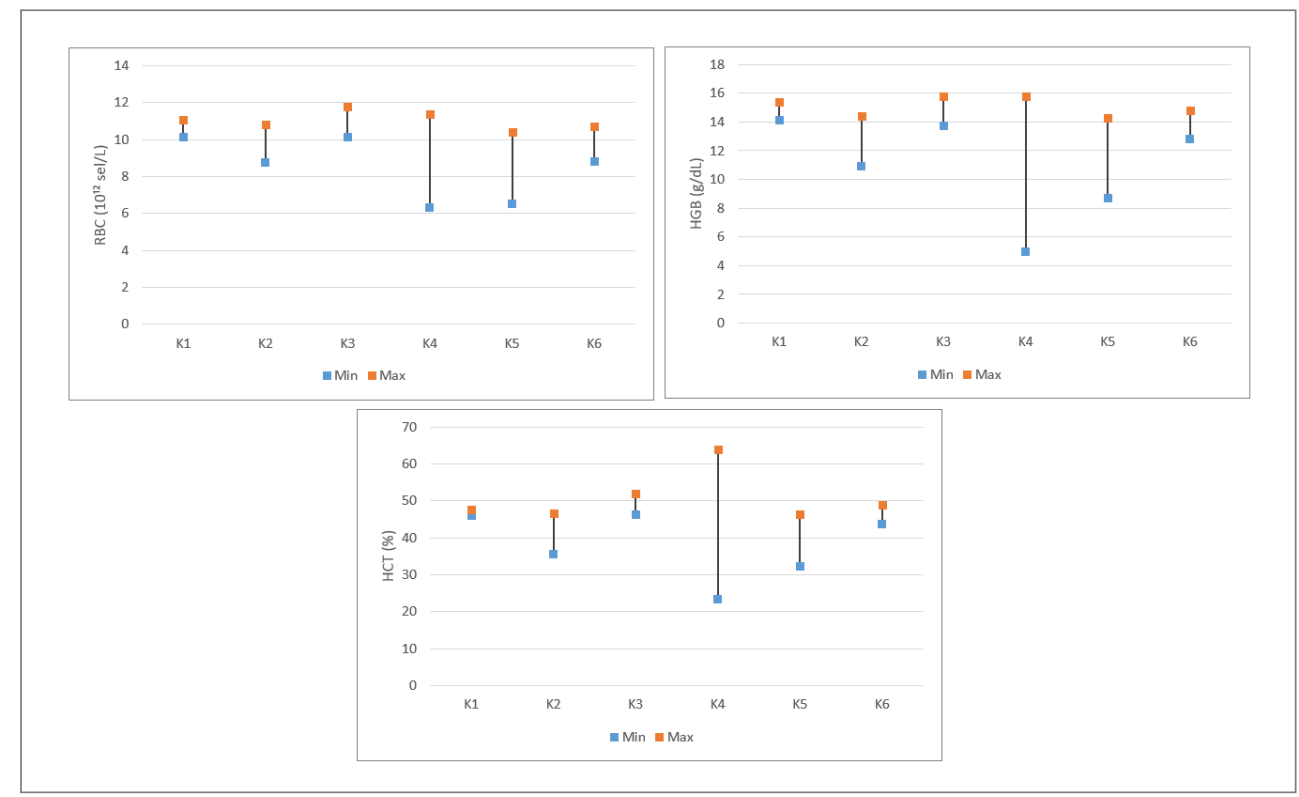

Fig. 2. The results of the first measurement: total erythrocyte count (RBC), hemoglobin level (HGB), and hematocrit value (HCT) of mice after being infected with $S$. aureus (K-1, K-2, K-3, K-4, K-5, K6) $1 \times 10^{\wedge} 8 \mathrm{CFU}$ bakteri/mL intraperitoneal (IP)

All groups (except K-3) were then given treatment. Group K-1 was the group of mice treated with tetracyclin antibiotics, group K-2 was given the antibiotic erythromycin, groups K-4, K-5, and K-6 were treated with extracts of Persea americana, respectively, the dose of $300 \mathrm{mg} / \mathrm{kb}$ $\mathrm{BW}, 600 \mathrm{mg} / \mathrm{kb} \mathrm{BW}$, and $1200 \mathrm{mg} / \mathrm{kg} \mathrm{BW}$ for 7 days.

The results of the hematological examination after the treatment are listed in Figure 3 below. The results of the second examination (the 7th day post $S$. aureus infection and after therapy) on the leucocytes and the leukocytes differential on K-1 showed lymphopenia, on K-2 was normal, on K-3 was lymphopenia. Before being given tetracyclin treatment, K-1 showed leukopenia and lymphopenia. Group K-2 before being given erythromycin showed lymphopenia, monocytosis, neutrophilia.

The second examination results on leukocytes and leukocyte differentials on K-4 was normal, K-5 was neutrophilia with normal leukocytes, K-6 was leukopenia with lymphopenia. The first examination on K-4 and K-5 were leukopenia is accompanied by lymphopenia and neutrophilia, in K-6 was leukopenia is accompanied by lymphopenia, neutrophilia, monocytosis. Avocado seeds have a potentially effect as antibacterial. ${ }^{[26]}$

Group K-4 was the group given avocado seed extract at a dose of $300 \mathrm{mg} / \mathrm{g} \mathrm{BW}$, and K-5 was the group given avocado seed extract at a dose of $600 \mathrm{mg} / \mathrm{kg} \mathrm{BW}$. Both groups showed improvement in total leukocytes and their components. On the other hand, K- 6 (the group given avocado seed extract at a dose of $1200 \mathrm{mg} / \mathrm{kg} \mathrm{BW}$ ) did not show any improvement, there was still leukopenia even though only the lymphocyte component decreased. 


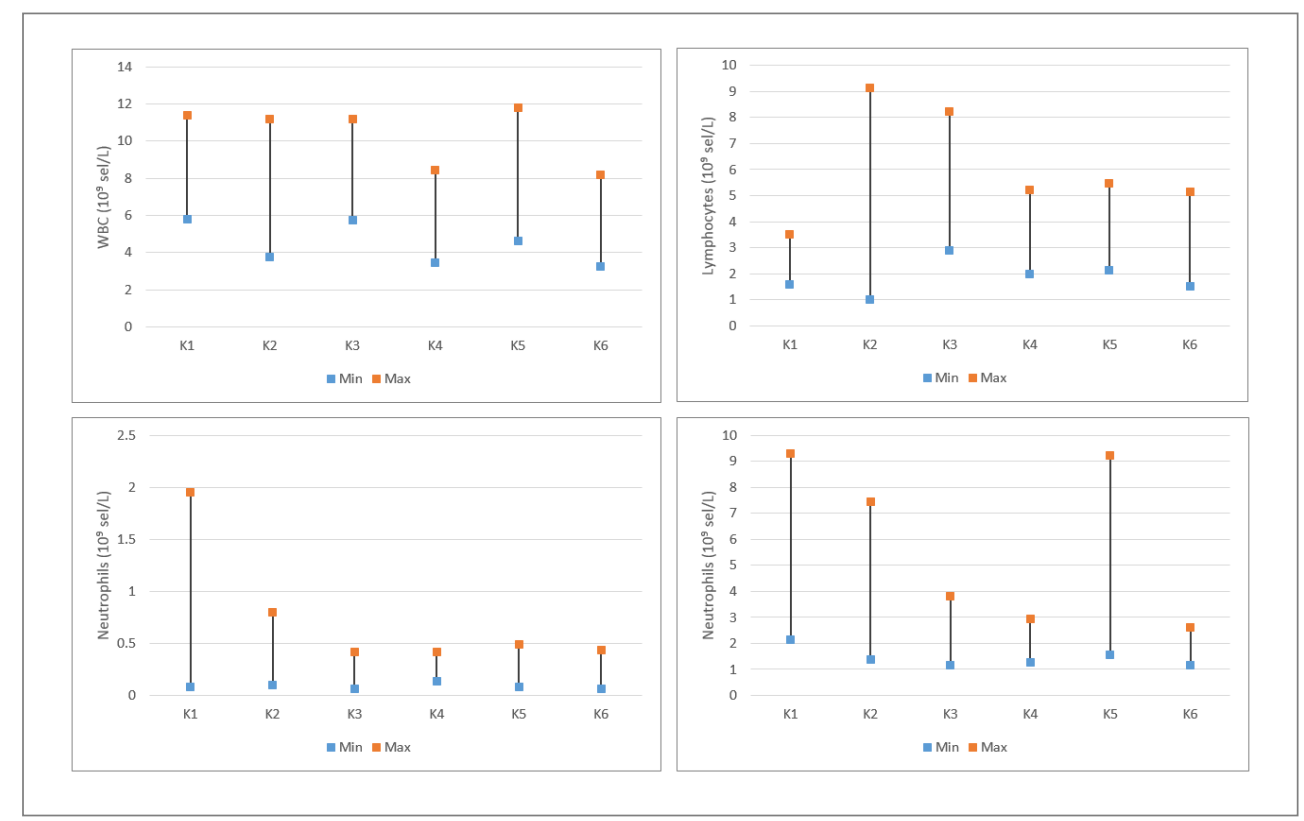

Fig. 3. Second examination results: leukocyte count and leukocyte differential of mice after being infected with $S$. aureus (K-3) only, after being infected with $S$. aureus and given antibiotics (K-1, K2); and infected with $S$. aureus then given Persea americana extracts (K-4, K-5 and K-6)

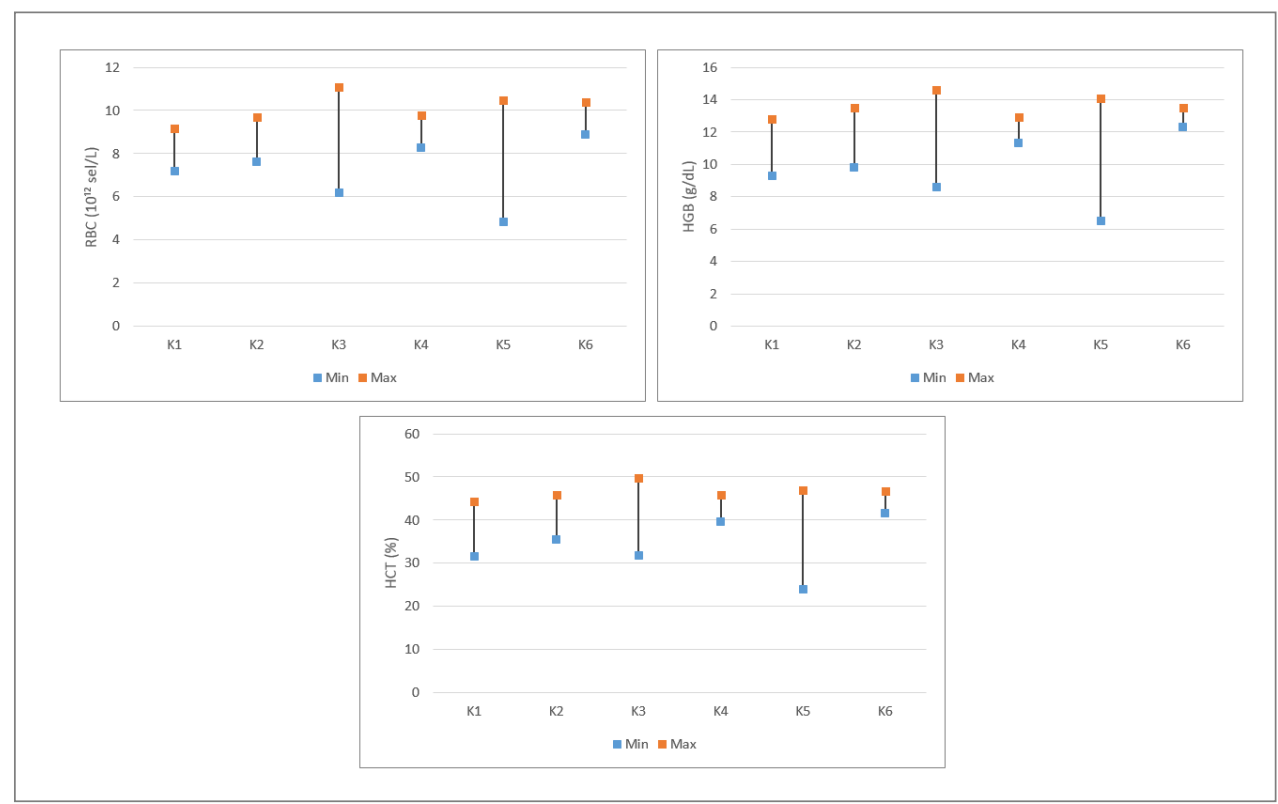

Fig. 4. Second test results: calculation of the total erythrocyte count (RBC), hemoglobin level (HGB), and hematocrit value (HCT) of mice after being infected with $S$. aureus (K-1, K-2, K-3, K- 4, K-5, K6) $1 \times 10^{\wedge} 8 \mathrm{CFU}$ of bacteria/mL intraperitoneal (IP) and respectively given antibiotics (K-1, K-2), and given the extract of Persea americana (K-4, K-5, K-6) and without treatment (K-3) 
The calculation of the RBC, HGB and HCT is summarized in Figure 4 above. The results showed normocytic normochromic anemia at K-1, K-2, and K-3. Previously, at first examination it was found that there was indeed microcytosis, which usually preceded anemia or during anemia. On the second examination, where anemia was found, it was stated that the administration of antibiotics had not given the maximum effect of treatment, which was evident in these three groups. Groups K-2 and K-3 are known to have normocytic normochromic anemia, just like $\mathrm{K}-1$.

The first examination on K-4 showed microcytic hypochromic anemia and then on the second examination showed improvement, it was found that the mice were not anemic. The results of the second examination on K-5 still showed normocytic normochromic anemia, the same as the results of the first examination. The results of the second examination on K-6 showed has not anemia, compared to the condition of microcytosis in the previous examination. The results of RBC, HGB and HCT examinations on K-4, K-5, K-6 showed that administration of doses of $300 \mathrm{mg} / \mathrm{kg}$ and $1200 \mathrm{mg} / \mathrm{kg} \mathrm{BW}$ improve conditions of anemia. Table 1 below presents a summary of the results obtained from the first and second blood measurements of the six groups of experimental mice.

Table 1. Summary of the first (after $S$. aureus injection) and second (after therapy/treatment/extract of $P$. americana administration) hematology results in $\mathrm{K}-1, \mathrm{~K}-2, \mathrm{~K}-3, \mathrm{~K}-4, \mathrm{~K}-5$, and $\mathrm{K}-6$

\begin{tabular}{|c|c|c|c|c|}
\hline \multirow{3}{*}{$\begin{array}{l}\text { Group } \\
\mathrm{K}-1\end{array}$} & \multicolumn{4}{|c|}{ Blood collection } \\
\hline & \multicolumn{2}{|c|}{ after $S$. aureus injection (Day 1) } & \multicolumn{2}{|c|}{$\begin{array}{c}\text { after treatment of P. americana } \\
\text { etanol extract (Day 7) }\end{array}$} \\
\hline & $\begin{array}{l}\text { leukopenia, } \\
\text { lymphopenia }\end{array}$ & microcytosis & limphopenia & $\begin{array}{l}\text { normocytic } \\
\text { normochromic } \\
\text { anemia }\end{array}$ \\
\hline $\mathrm{K}-2$ & $\begin{array}{l}\text { Potentially } \\
\text { leukopenia, } \\
\text { limphopenia, } \\
\text { monocytosis, } \\
\text { neutrophilia }\end{array}$ & microcytosis & Normal & $\begin{array}{l}\text { normocytic } \\
\text { normochromic } \\
\text { anemia }\end{array}$ \\
\hline K-3 & $\begin{array}{l}\text { Potentially } \\
\text { leukopenia (very } \\
\text { low threshold } \\
\text { leukocytes) }\end{array}$ & microcytosis & limphopenia & $\begin{array}{l}\text { normocytic } \\
\text { normochromic } \\
\text { anemia }\end{array}$ \\
\hline K-4 & $\begin{array}{l}\text { leukopenia, } \\
\text { limphopenia, } \\
\text { neutrophilia }\end{array}$ & $\begin{array}{l}\text { microcytic } \\
\text { hypochromic } \\
\text { anemia }\end{array}$ & Normal & Normal \\
\hline K-5 & $\begin{array}{l}\text { leukopenia, } \\
\text { limphopenia, } \\
\text { neutrophilia }\end{array}$ & $\begin{array}{l}\text { normocytic } \\
\text { normochromic } \\
\text { anemia }\end{array}$ & neutrophilia & $\begin{array}{l}\text { normocytic } \\
\text { normochromic } \\
\text { anemia }\end{array}$ \\
\hline K-6 & $\begin{array}{l}\text { leukopenia, } \\
\text { limphopenia, } \\
\text { neutrophilia, } \\
\text { monocytosis }\end{array}$ & microcytosis & $\begin{array}{l}\text { leukopenia, } \\
\text { limphopenia }\end{array}$ & Normal \\
\hline
\end{tabular}




\section{Conclusions}

It was concluded that $S$. aureus $1 \times 10^{8} \mathrm{CFU} / \mathrm{mL}$ intra peritoneal (IP) infection caused leukopenia and was potentially followed by lymphopenia, neutrophilia, and monocytosis in mice. The occurrence of microcytosis can lead to anemia, which can be categorized as microcytic hypochromic or normocytic normochromic. Administration of $P$. americana extract at a dose of $300 \mathrm{mg} / \mathrm{kg} \mathrm{BW}(\mathrm{K}-4)$ for 7 days after $S$. aureus infection was found to be effective in improving of hematological values in mice back to normal.

This study was supported by the Department Development Grant (BPPTN-BH) of the Faculty Veterinary Medicine - Universitas Gadjah Mada grant no. 1334/UN1/FKH/HK4/2020. The authors would like to thanks Dion A. Dewananda, DVM as well as the laboratory staffs and students (Ajeng, Ayesah and Yasinta) for providing technical supports during the research.

\section{References}

1. Y. Le loir, F. Baron, M. Gautier, Genet. Mol. Res. 2, 1 (2003)

2. T. Na'was, A. Hawwari, E. Hendrix, J. Hebden, R. Edelman, M. Martin, W. Campbell, R. Naso, R. Schwalbe, A.I. Fattom, J. Clin. Microbiol. 36, 2 (1998)

3. D. Nashev, K. Toshkova, L. Bizeva, Ö. Akineden, C. Lämmler, M. Zschöck, Letters in Appl. Microb. 45, 6 (2007)

4. T. Khana, R. Frienship, C. Dewey, J.S. Weese, Elsevier Vet. Microb. 128 (2008)

5. E. van Duijkeren, R. Ikawaty, M. Broekhuizen, M.D. Jansen, E.C. Spalburg, A.J. de Neeling, J.G. Allaart, A. van Nes, J.A. Wagenaar, A.C. Fluit, Vet. Microbiol. 126 (2008)

6. S.I.O. Salasia, Khusnan, C. Lämmler, H. Nirwati, J. Biotech. (2003)

7. S.I.O. Salasia, Khusnan, C. Lämmler, M. Zschöck, J. Vet. Sci. 5, 2 (2004)

8. S.I.O. Salasia, M. Haryadi, Khusnan, J. Sain Vet. 23, 2 (2005)

9. S.I.O. Salasia, Khusnan, Sugiyono. J. Vet. 10, 3 (2009)

10. S.I.O. Salasia., S. Tato, Sugiyono, D. Ariyanti, F. Prabawati, J. Vet. Sci. 12, 4 (2011)

11. S.I.O. Salasia, S. Tato, F. Prabawati, D. Ariyani, J. Kedokteran Hewan 7, 2 (2013)

12. T.W.R. Chia, and G.A. Dykes, Pharm. Biol., 48, 7 (2010)

13. Sutrisno, S. Marfu'ah, L. Oktaviana, Ekstraksi fraksi non-polar dari biji alpukat Persea americana, Mill dan uji aktivitas sebagai antibakteri. In Proceedings of Seminar nasional kimia dan pendidikan HKI cabang Sumbar Padang. (7 $7^{\text {th }}$ Desember 2013)

14. W. Jannah, N. Rahman, Ratman, J. Akademika Kimia 6, 3 (2017)

15. A.H. Bujung, H. Homenta, J.A. Khoman. J. e-G. 5, 2 (2017)

16. T.B. Bahru, Z.H. Tadele, E.G. Ajebe, Chem. Sci. Int. J. 27, 2 (2019)

17. J.J.G. Leite, E.H.S. Brito, R.A. Cordeiro, R.S.N. Brilhante, J.J.C. Sidrim, L.M. Bertini, S.M.D. Morais, M.F.G. Rocha, M.F.G, Revista da Sociedadae Brasileira de Medicina Tropical 2, 42 (2009) 
18. R. Retnosari, Sutrisno, K. Handoyo, Journal Cis-Trans (JC-T) 1, 1 (2017)

19. W.L. Drew, A.L. Barry, R. O’Toole, J.C. Sherris, Appl. Microb. 24, 2 (1972)

20. C. M. Santosa, I. Rosyadi, D. Arifianto, S.I.O. Salasia, J. Sain Vet. 37, 2 (2019)

21. D.M. Moore. Hematology of the Mouse (Mus musculus). In: Schalm's Veterinary Hematology. B.F. Feldman, J.G. Zinkl, N.C. Jain. (Eds.) $5^{\text {th }}$ ed. Lippincott Williams and Wilkins. Philadelphia. USA (2000)

22. A.P. Bolliger, N.E. Everds, K.L. Zimmerman, D.M. Moore, S.A. Smith, K.F. Barnhart, Hematology of Laboratory Animals. In: Schalm's Veterinary Hematology. Weiss and Wardrop (eds.). $6^{\text {th }}$ ed. Blackwell publishing Ltd. USA (2010)

23. N.C. Jain, Schalm's Veterinary Hematology. $4^{\text {th }}$ ed., Lea and Febiger. Philadelphia, USA (1986)

24. B.J. Mitruka, H.M. Rawnsley. Clinical Biochemical and Hematological Reference Values in Normal Experimental Animals and Normal Humans. $2^{\text {nd }}$ ed. Masson, New York, USA (1981)

25. R.E. Kristanty, J. Suriawati, J. Sulistiyo. Cytotoxic Activity of Avocado Seeds Extracts (Persea americana Mill) on T4/D Cell Lines. Int. Res. J. Pharm 5 (7). (2014)

26. P.F. Cardoso, J.A. Scarpassa, L.G. Pretto-Giordano, E.S. Otaguiri, S.F. Yamada-Ogatta, G. Nakazato, M.R.E. Perugini, I.C. Moreira, G.T. Vilas-Boas. Antibacterial Activity of Avocado Extracts (Persea americana, Mill) against Streptococcus agalactiae. PYTON 85. 2016 